\title{
Bohatí a mocní jako subjekty sociální pastorace
} Michal Opatrný

Známý kněz, který je farářem v prestižní bratislavské čtvrti, mi jednou vyprávěl své první zážitky z této farnosti. Jde o farnost, kde bydlí lidé, kteří jsou bohatí nejen na poměry dnešního Slovenska. Jde také o lidi, kteři často disponují určitou mírou moci, kterou jim propưjčuje jejich majetek nebo jejich profese. Při prvním setkání mého známého s těmito farníky mu bylo z jejich strany sděleno, že nechtějí, aby jim řikal, co mají dělat - že je to jejich farnost a oni chtějí sami realizovat to, co považují za dobré a potřebné, aby se ve farnosti dělalo. Domnívám se, že tato situace velmi dobře vystihuje, kdo jsou „bohatí a mocní" dneška. Minimálně z pastorálního hlediska vidím takło zaznamenanou zkušenost jako jejich velmi dủležitou charakteristiku.

$\checkmark$ této studii chci proto nejprve popsat specifickou metodu pastorační práce, která se nazývá sociální pastorace, abych pak mohl ukázat, proč a jak je z pastoračního hlediska tato charakteristika „bohatých a mocných" důležitá.

\section{Sociální pastorace}

Sociální pastorací nazval Hermann Steinkamp svou úpravu latinskoamerické aplikace klasické pastorální metody Vidět-Posoudit-Jednat. ${ }^{1}$ Zcela jednoduše vyjádřeno, jde ve Steinkampově sociální pastoraci o vytvoření solidarizujícího společenství, kterým může být např. farnost, skupina mládeže, svépomocná skupina nebo skupina pracovníků v pomáhající profesi. ${ }^{2}$ Jádro metody totiž tvoří Steinkampovo přesvědčení, že pastorace nespočívá ani tak v "kázání o spáse“ jako v určitém zpưsobu života a prístupu k druhým lidem. Vrcholem sociální pastorace se pak stává chvíle, kdy se bohatí učí od chudých, resp. zdraví od nemocných, nepostižení od osob s postižením, pomáhající od těch, kterým je pomáháno. Jinak řečeno, své plné síly dosáhne sociální pastorace tehdy, když se pomáhající naučí od svých klientů tomu, jak jim lze pomoci. ${ }^{3}$

Steinkamp přitom vychází z toho, že se i Ježíš Kristus se svým učením nevnucoval a se svojí nabídkou spásy se nepodbízel - jeho nabídka byla bez-mocná, a to do té míry, že ho to nakonec stálo život. ${ }^{4}$ Přes svou nenucenost se totiž zároveň zcela bezprostředně týkala toho, co je v lidském životě a mezilidských vztazích nezdravé. Ježíš nenabízel útěchu oním světem, jeho slova a činy se týkaly prítomnosti a životů těch, se kterými hovořil. ${ }^{5}$ Steinkamp se proto domnívá, že vytváření nebo udržování rozštěpení mezi službou člověku v jeho nouzi

\footnotetext{
1 Uvedené aplikace a procesy jejich přebírání a modifikování jsem podrobněji popsal ve své studii o metodách práce duchovní služby u policie. Zde je nutné připomenout, že Steinkamp přebírá myšlenky určitého středového proudu teologie osvobození, kterému je velmi blízká opce pro chudé, a klade důraz na praktické lidské jednání, ale zároveň nepřipouští násilí a s ním i revoluci jako metodu osvobození. Naopak zdưrazňuje duchovní rozměr a význam praktického lidského jednání tak, jak o tzv. lidské činnosti hovoří např. konstituce Gaudium et spes zejména ve čl. 34; srov. Michal OPATRNÝ, „Pracovní metody duchovní služby," in Východiska a perspektivy duchovní služby u policie, ed. Michal OPATRNÝ - Jaroslav KOZÁK - Jiří LANKKA - Roman MİČKA, České Budějovice: TF JU, 2012, s. 105-126.

2 Srov. Herman STEINKAMP, Sozialpastoral, Freiburg i. Br.: Lambertus, 1991, s. 85-145. Steinkamp se k sociální pastoraci naposledy zásadně vyjádřil ve své knize Diakonie statt Pastoral: Ein überfälliger Perspektivenwechsel, Münster: Lit, 2012, 342 s., kde navazuje na svou dosavadní práci, a proto přebírá celé pasáže ze svých starších publikací. Rozhodl jsem se proto odkazovat zde na jeho starší práci, kde je sociální pastorace popsána podrobněji než v uvedené poslední souhrnné publikaci.

3 Srov. tamtéž, s. 121, 144nn

4 Srov. tamtéž, s. 127-128.

5 Srov. tamtéž, s. 126.
} 
a potřebách a hlásáním Božího slova či bohoslužbami, je fatálním omylem západního křest'anství, tedy nejen římskokatolické církve, ale i luterské a kalvínské tradice, protože učení Ježíše Krista nemůže být jen kázáno pomocí slov, ale musí být především prakticky uskutečňováno prostřednictvím jednání - třeba i beze slov. ${ }^{6}$ Pastorací je tak podle Steinkampa vlastně každé jednání ve prospěch druhého člověka. Křest'ané se podle něj proto hluboce mýlí, a směřují tak svou pastorační práci mimo realitu, když oddělují slova od činů, protože Ježíšova slova vždy souvisela s jeho konkrétními činy nebo s konkrétními lidskými životy těch, se kterými se potkal. ${ }^{7}$

Jako zdůvodnění tohoto názoru Steinkamp uvádí svůj výklad podobenství o milosrdném Samařanovi (L 10,25-37). Když byl Ježíš „náboženským expertem“ - jak Steinkamp zákoníka nazývá - dotázán, co má dělat, aby získal věčný život, nepředloží mu propracovanou teologickou definici spásy, ale vypráví mu jako odpověd' podobenství. Ovšem ještě před začátkem vyprávění je zákoník Ježíšem vyzván, aby si odpověděl sám podle toho, co se uvádí v Zákoně (L 10,26). Na jeho přesnou teologickou definici, co má dělat, aby byl spasen - milovat Boha a milovat bližního jako sebe sama (L 10,27), mu Ježíš odpovídá zcela jednoduše, že má prostě činit to, co právě řekl (L 10,28). Samotný příběh o Samařanovi je pak podle Steinkampa už jen názorným příkladem dokreslujícím tuto stručnou Ježíšovu odpověd'. Steinkamp se domnívá, že právě v ní je skryta celá podstata příběhu o milosrdném Samařanovi: „Slova a teorie o spáse jsou bez odpovídajícího jednání naprosto bezcenné! Jenom důvěryhodná uzdravující (něm. heilende, pozn. aut.) praxe je ,místem', kde může být zažita spása (něm. Heil, pozn. aut.)." ${ }^{8}$ A to přesně v intencích uvedeného podobenství, kde se na konci Ježíš ptá opačně než zákoník na začátku. Vyprávěné podobenství začalo zákoníkovou otázkou "Kdo je můj bližní?" (L 10,29), ale na konci už stojí otázka jiná: „Kdo byl bližním tomu, který upadl mezi lupiče?“ (L 10,36) Podle Steinkampa to znamená, že pomáhající je zároveň obdarovaný - z pomáhajícího se stal bližní, kterému bylo pomoženo. Situace, kdy člověk může někomu pomoci, je tak podle něj chvílí, kdy pomáhající zažívá spásu. Podle Steinkampa proto v podobenství o milosrdném Samařanovi vůbec nejde o povinnost pomoci tomu, kdo to potřebuje. Nejde ani o dobře zakamuflovanou formulaci náboženského předpisu lásky k bližnímu. To by podle něj bylo hrubým neporozuměním příb̌hu, protože by tu opět šlo o to, co člověk vykonal vlastními silami a za cenu vlastního vypětí. ${ }^{9}$ Podle tohoto výkladu chce tedy podobenství o milosrdném Samařanovi říci především to, že každá situace, kdy lze někomu pomoci, je pro pomáhajícího zkušeností spásy, protože zažívá k druhému člověku takový vztah, jaký má k lidem Bủh. Právě proto se ale při každém pomáhání také jedná o skutečnou pastoraci.

Ježišův př́slib věčného života bez utrpení a smrti, kterého se člověku po pozemském utrpení a smrti dostane, by byl podle Steinkampa naprosto nedůvěryhodný, pokud by člověk nemohl nějakým způsobem už nyní zakusit, v čem tento věčný život spočívá. ${ }^{10}$ Zkušenost spásy tedy může podle Steinkampa udělat člověk tehdy, když dokáže zdravě vyvážit své vztahy k druhým lidem i sám k sobě. To ale nikdo z lidí vlastními silami nedokáže, takže vzácné chvíle, kdy se to podaří, jsou vlastně darem od Boha, který se tak dává člověku v jeho mezilidských vztazích poznat.

V intencích Steinkampovy sociální pastorace tak můžeme říci, že v pastorální praxi je důležité jen takové jednání pastoračního pracovníka, které lidem kolem něj umožní získat zkušenost, v čem spása spočívá.

6 Srov. tamtéž, s. 130

7 Srov. tamtéž, s. 122.

8 Tamtéž, s. 130.

9 Srov. tamtéž, s. 131.

10 Srov. tamtéž, s. 122-126.. 


\section{„Bohatí a mocní“ jako subjekt pastorace}

Vzhledem k doposud uvedenému je na místě se ptát, jak a zda vůbec metoda sociální pastorace, která se díky své inspiraci v teologii osvobození jeví jako principielně zaměřená na "chudé“ (v širokém slova smyslu), může souviset s pastorací „bohatých a mocných“. Pokud by ovšem sociální pastorace byla opravdu metodou principielně zaměřenou na "chudé", pak by taková otázka byla na místě. Problematika „chudých“ je všakjen kontextem, ze kterého vzniká. Klíčový pojem teologie osvobození strukturální zlo, resp. sociální zlo, strukturální hřích nebo sociální hřích, totiž implikuje, že zlem, které se stalo strukturou společnosti, jsou postiženi všichni její členové, je jím postižena společnost jako celek. Proto může každý člen společnosti za určitých okolností učinit zkušenost spásy tím, že bude skrze solidaritu strukturální zlo překonávat. Stejně tak další klíčový pojem teologie osvobození, totiž opce pro chudé, vůbec z pastorace nevylučuje bohaté, právě naopak. Opce pro chudé je rozhodnutím latinskoamerických místních církví být ve své zemi církví pro chudé. To znamená, že se má týkat také a především středostavovské a bohaté části církve. Právě ti křest'ané, kteří nejsou "chudí“, mají být křest’any pro „chude“".

Ke Steinkampově koncepci můžeme díky fenomenologii práce pocházející od Jozefa Tischnera také dodat, že prakticky každá profese ze své podstaty poskytuje pro zkušenost spásy poměrně velký prostor, protože plody její práce zpravidla využívá někdo jiný. ${ }^{11}$ Steinkampova sociální pastorace tak podle mne do značné míry vystupuje z prostoru pomáhajících profesí a pomáhání, protože má ve skutečnosti mnohem širší záběr a mohla by být interpretována i jako určitý druh spirituality.

$\mathrm{V}$ rámci své koncepce sociální pastorace to Steinkamp upřesňuje za pomoci poměrně zajímavého př́ikladu, který se týká právě „světa práce“. Ve vyspělých zemích je podle něj možné konstatovat zdeformované pojetí práce, kdy je člověk definován podle toho, zda má zaměstnání a jak prestižní nebo výnosné toto zaměstnání je. Viditelným dopadem této specifické podoby strukturálního zla je skutečnost, jaké osobní utrpení a rodinné tragédie způsobuje v těchto „vyspělých“ zemích nezaměstnanost. Kdo nemá zaměstnání, je méněcenný. Druhou podobou uvedeného dopadu strukturálního zla je podle Steinkampa workoholismus. Za závislostí na práci v zaměstnání podle něj v důsledku stojí stejné zdeformované pojetí práce - dobrým, užitečným, láskyhodným a sebe-láskyhodným člověkem budu jen tehdy, když budu ještě o něco více pracovat, když si v práci vydobudu ještě prestižnější pozici a ještě lepší plat. Proto by na řešení svých problémů měli podle Steinkampa nezaměstnaní a workholici pracovat společně - měli by spolupracovat v rámci svépomocných skupin, protože jsou postiženi jedním a tím samým problémem. Církve, resp. farnosti, by pro takovou spolupráci měli vytvářet prostor. Této problematice by se křest'ané podle Steinkampa měli věnovat proto, že právě chvíle, kdy si tito lidé, které spojuje stejný problém, dokáží ve své vzájemné solidaritě pomoci, jsou okamžikem, kdy mohou zakoušet spásu. Právě proto jde o pastoraci. ${ }^{12}$

Do uvedeného Steinkampova příkladu lze celkem snadno dosadit "bohaté a mocné"; mj. právě proto, že jsou to především oni, kdo bývají postiženi problémem workoholismu. Už jen z uvedeného příkladu proto vyplývá, že sociální pastorace ve Steinkampově pojetí je pro pastoraci „bohatých a mocných“ velmi vhodnou metodou. Otázka, kterou by měla kvưli pastoraci „bohatých a mocných“ praktická teologie zodpovědět, tedy zní, co spojuje tyto lidi s lidmi jinými, zejména „chudými“. Opce pro chudé je totiž v sociální pastoraci zásadní,

11 Srov. Jozef TISCHNER, Etika solidarity, München: Opus bonum, 1985, s. 15-17.

12 Srov. STEINKAMP, Sozialpastoral, s. 89-103. 
nelze od ní až na výjimky abstrahovat. ${ }^{13}$ Odpovědí však určitě nemůže být výzva k přesunu peněz od bohatých k chudým. Tím by se vytratila veškerá existenciálnost sociální pastorace, protože by v ní chyběl faktický vztah. Skrze odosobněné peníze by vlastně ani žádný vztah nebyl navázán. Proto by bylo možná lepší položit otázku jinak - jako jednu podvojnou otázku: Co mohou "chudí" nabídnout „bohatým a mocným“? A co mohou „bohatí a mocní" nabídnout chudým?

\section{Co mohou "chudîi" nabídnout "bohatým a mocným"}

Hledáme-li, co je potenciálem „chudých“, který jim umožňuje nabídnout něco ostatním, je nasnadě, že "chudí" dokáží žít jinak než zejména a právě „bohatí a mocní“. Disponují uměním žít život tak, jak si to „bohatí a mocni“" často ani neumí představit. „Chudí" dokáží zpravidla vyjít se zcela jiným měsíčním rozpočtem domácnosti než bohatí a mocní. Obejdou se bez výrobků a služeb, bez kterých si „bohatí a mocní" nedokáží svůj život představit - nedokáží si představit, že by bez nich mohli vůbec nějak fungovat. ${ }^{14} \mathrm{Z}$ pastorálního hlediska je tedy třeba se ptát, zda a jak se v tomto smyslu učení bohatých od chudých, úspěšných od neúspěšných může stát součástí pastorace?

Domnívám se, že právě v této souvislosti stojí za to, oprášit zkušenost starověkých křest'anů, kteří - jak připomněl Benedikt XVI. ve své druhé encyklice Spe salvi - znázorňovali Krista jako filosofa, což nemělo vyjádřit nic jiného, než že právě Ježíš Kristus je učitelem života:

„Filozof byl (...) ten, kdo uměl učit hlavnímu umění: umění opravdově být člověkem - umění žít a umřít. (...) Existuje dětský sarkofág z konce 3. století z Říma, na němž se v kontextu Lazarova vzkříšení poprvé objevuje postava Krista jako pravého filosofa, který v jedné ruce drží evangelium a v druhé hưl pocestného, tedy znak filozofa. Touto svou holí vítězí nad smrtí; evangelium přináší pravdu, kterou potulní filozofové marně hledali. " 15

Radikální chudoba, ke které Ježíš při vyslání do světa vyzýval nejbližší okruh svých učedníků (Mk 6,8-11; Mt 10,5-15; L 9,2-5 a 10,2-12) a kterou zřejmě sám praktikoval, nabízí právě srovnání $\mathrm{s}$ tehdejšími potulnými filosofy různého názorového zaměření. Důvod $\mathrm{k}$ chudobě u Ježíše a jeho učedníků se však od nich zásadně liší. Chudoba Ježíše a jeho učedníků má být odkazem na nový řád Božího království. Nevyjadřovala tedy pohrdání majetkem nebo světem obecně, ale měla ukazovat, že řád Božího království, které s Ježíšem přichází, je podstatně odlišný od i tehdy vládnoucího řádu vlastnictví, zisku, bohatství a zneužívání lidí ve svém okolí. ${ }^{16}$ Ježíš tedy svým praktickým jednáním, ve kterém se podobal potulným filosofưm, dával najevo, že spolu s ním přichází jiný způsob života. Díky tomu, že ho sám konsekventně praktikoval, byl pro ostatní vzorem a učitelem. Právě proto se domnívám, že pojetí Krista jako „filosofa -

13 Sám Steinkamp od opce pro chudé abstrahuje snad jen v případě aplikace sociální pastorace na přípravu na manželství, i když mu ve skutečnosti příprava na manželství možná spíše slouží jen jako příklad k vysvětlení některých aspektů sociální pastorace; srov. Hermann STEINKAMP, ,",Leiten heißt Beziehung stiften.', Ja aber...," Theologisch-Praktische Quartalschrift 4/2003, s. 339-347.

14 Tato situace byla plasticky znázorněna ve třetím dílu seriálu České televize Nevinné lži (2013) s názvem Druhý dech, který režíroval Petr Zahrádka, scénář napsala Mirka Zlatníková. Jiří Langmajer zde ztvárnil hlavní roli krizového manažera, který léta vyhazoval lidi z práce, až byl jednou z práce vyhozen i on sám. Novou práci, která by byla podobná té předchozí a za kterou by dostával obdobně vysoký plat, se mu však najít nedaří. Přesto nejen své ženě, přátelům a známým, ale především sám sobě nalhává, že se nic nestalo a že ve svém životě nebude muset nic změnit. Nedokáže si totiž představit, že opustí svůj dosavadní způsob života. Neumí žít jinak. Až když se ocitne skutečně na ulici, nemá už vůbec nic a ujme se ho jeho bývalý účetní, kterého kdysi vyhodil, naučí se žít jinak a nakonec se i vrátí ke své rodině.

15 Spe salvi 6.

16 Srov. Joachim GNILKA, Wie das Christentum entstand: Jesus von Nazaret: Botschaft und Geschichte, sv. 1, Herder: Freiburg i. Br. - Basel - Wien, 2004, s. 175-177. 
učitele života“ může být tím, na čem by měla pastorace, při které se „bohatí a mocní“ budou učit od „chudých", stavět.

Stejně tak lze vzít za inspiraci pro tento druh pastorace i druhý způsob znázornění Krista, který byl používán ve starověku. Šlo o obraz pastýře, který je opět zmíněn ve Spe salvi v souvislosti s obrazem Krista jako filosofa. ${ }^{17}$ Pozdější vývoj v sakrálním i lidovém umění tento motiv redukoval prakticky na jediné téma - Kristus jako pastýř hledající či přinášející ztracenou ovci. Římský občan se však na pastýře díval ještě jiným způsobem:

„Podobně jako v př́ípadě ztvárnění filozofa, také pokud jde o pastýřovu postavu, se prvotní církev mohla inspirovat v již existujícím římském umění. Pastýř zde byl obecným znázorněním vysněného klidného a prostého života, po němž lidé v chaotickém velkoměstě toužili." ${ }^{18}$

Proto se domnívám, že vedle pojetí Krista-Filosofa může být pro pastoraci, kdy se „bohatí a mocní" učí od ",chudých“, přínosné i pojetí Krista jako Pastýře - vzoru prostého života, ovšem právě nikoliv ve smyslu pastýře hledajícího a přinášejícího zpět ztracenou ovci. Již zmíněný

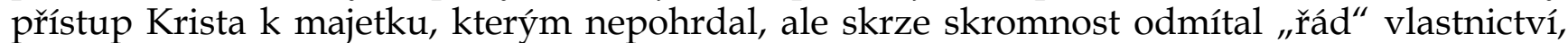
zisku, bohatství a zneužívání druhých, konverguje i s chápáním Krista-Pastýře ve starověkém Římě. Kristus-Filosof je tak učitelem života a Kristus-Pastýř vzorem správného př́stupu k majetku, druhým lidem i sobě samému. Dietrich Bonhoeffer to stručně vyjádřil tak, že mezi sebe a majetek nebo i druhé lidi včetně nejbližších je třeba postavit Krista - získat k nim vztah po vzoru Krista. ${ }^{19}$ Ten majetkem nepohrdá, ale nenechává se jím ovládnout, druhé nezneužívá, ale respektuje je a podporuje - a právě díky tomu je jeho život klidný a prostý.

Proto je třeba se ptát, jak tyto obrazy Krista využít v pastoraci, zejména pak v sociální pastoraci, kdy se „bohatí a mocní“ mají učit od "chudých“. Chtěl bych zde naznačit jeden z možných př́ístupů.

Co se vztahu k druhým lidem týká, jsou křestané povoláni především k tomu, aby vydávali svědectví o Bohu - tzn. aby před lidmi, se kterými se setkávají, vydávali svým životem svědectví, že Bůh je těmto lidem mnohem blíž, než si sami myslí; dokonce blíž, než jsou jim právě sami křest'ané. ${ }^{20}$ Kristus potřebuje svědky i tehdy, pokud je chápan především jako učitel života (filosof) a vzor prostého života (pastýř). Potřebuje křest'any, kteří by před světem a zejména před „bohatými a mocnými“ dosvědčovali, že je to právě Ježíš Kristus, u koho se lze naučit prostému životu. Svědectví je přitom samotným jádrem pastorace, pokud ji chápeme tak, že nejen pastorační profese, ale i křest'ané obecně jen asistují u vztahu Boha k člověku, na který člověk odpovídá opačným vztahem - svou vírou a jí odpovídající životní praxí. ${ }^{21}$ To, co mohou "chudí" - tzn. skutečně chudí, neúspěšní a životem porůznu zkoušení lidé - nabídnout „bohatým a mocným“ je právě svědectví o tom, že život lze žít i prostě. Pastorační práce by proto měla pracovat na uschopnění těchto lidí k takovému svědectví. Vyžaduje to především otevřenost pastorace světu „chudých“. Stejně tak česká situace, kdy mezi křest'any najdeme jen málo „bohatých a mocných“ a o to více „chudých", je pro to dobrou př́ležitostí.

\footnotetext{
17 Srov. Spe salvi 6.

18 Tamtéž.

19 Srov. Dietrich BONHOEFFER, Následování: Výklad kázání na hoře, bez uvedení nakladatele, místa a roku vydání, s. 61-63.

20 Originálně tuto problematiku rozpracoval Paul M. Zulehner za pomoci termínu mystagogická misie, kterým chce vyjádřit, že misie musí spočívat především v uvádění do tajemství - tzn. mystagogii, že Bůh doprovází každého člověka již od počátku jeho života; srov. Paul M. ZULEHNER, Kirche umbauen - nicht totsparen, Ostfildern: Schwabenverlag, 2004, s. 77.

21 Srov. Michal OpatrnÝ, „Impassibilis est Deus, sed non incompassibilis: Srovnání pohledů Jana Pavla II. a Benedikta XVI. na utrpení z pastorálního hlediska," Theologos 1/2011, s. 65-67.
} 


\section{Co mohou "bohatí a mocní“ nabídnout chudým}

Zkušenost mého známého kněze s pastorační prací ve farnosti „,bohatých a mocných“, kterou jsem zmínil v úvodu, je samozřejmě možné interpretovat jako projev pýchy „bohatých a mocných". V pastoraci by však neměly být pronášeny odsudky, zejména pak předběžné odsudky učiněné na základě povrchní zkušenosti a prvních dojmů. Jinak řečeno, je třeba se ptát, zda na uvedené charakteristice „bohatých a mocných“ dneška můžeme najít také něco pozitivního. $\mathrm{V}$ pastoraci by totiž především mělo jít o hledání dobra a odkrývání jeho původu v Bohu, jak to formuluje "metodologický“ článek pastorální konstituce II. vatikánského koncilu. ${ }^{22}$

Pokusíme-li se obecně vyjádřit náplň pastorační práce, pak v ní jde o to, podporovat jak jednotlivého člověka, tak společenství křestanů, aby se sami stávali subjektem pastorace. Člověk se tímto subjektem stává tehdy, když přebírá odpovědnost za svůj vztah k Bohu, druhým lidem, sobě samému a stvoření. Druhý vatikánský koncil to vyjadřuje těmito slovy:

„Písmo svaté totiž učí, že člověk byl stvořen ,k Božímu obrazu', dostal schopnost poznávat a milovat svého Stvořitele a byl od něho ustanoven pánem nad veškerým pozemským tvorstvem, (srov. Gn 1,26; Mdr 2,23) aby mu vládl a užíval ho k Boží slávě. (...) Důstojnost člověka tedy vyžaduje, aby jednal podle vědomé a svobodné volby, to znamená hýbán a podněcován $\mathrm{z}$ nitra osobním přesvědčením, a ne ze slepého vnitřního popudu nebo pouze z vnějšího donucení. ${ }^{23}$

Původcem lidské subjektivity je tedy Bůh, který člověka volá, aby se stával jeho obrazem. Ježíš Kristus je vzorem a příkladem pro toto stávání se subjektem. Zároveň je také vzorem pro pastorační práci, která v této logice jen a pouze asistuje uschopňujícímu a zmocňujícímu vztahu Boha k člověku a zároveň asistuje i vztahu člověka k Bohu, který je odpovědí na Boží povolání být subjektem. Odpovědí na povolání být subjektem pastorace proto nemůže být jen čistý akt víry, ale také praxe vztahů k druhým lidem, sobě a celému stvoření.

Nedokonalost a hříšnost člověka samozřejmě realizaci bytí subjektem negativně postihuje. ${ }^{24}$ Proto v případě určité životní praxe nemusí být vždy hned zřejmé, zda je projevem úsilí spolupracovat s Bohem na převzetí odpovědnosti za své vztahy k Bohu, druhým, sobě samému a stvoření, nebo projevem lidského egoismu a titánismu (V. Boublík). Usiluje-li však pastorace především o hledání dobra $\mathrm{v}$ člověku a jeho konání a v odkrývání původu tohoto dobra v Bohu, pak je nutné na praxi lidského života hledět nejprve touto optikou. Proto je třeba se ptát a zkoumat, zda životní praxe „bohatých a mocných“ je vždy jen směsicí pýchy, egoismu a titánismu, nebo je možné ji vidět i jako usilování o bytí subjektem. K člověku totiž patří, že jeho životní příběh většinou není extrémním zlem nebo dobrem, ale směsicí podléhání zlu a úsilí hledat dobro. ${ }^{25}$ Proto v životní praxi "bohatých a mocných" můžeme najít i mnoho př́ikladů úsilí o bytí subjektem.

Z tohoto úhlu pohledu lze říci, že jsou to právě „bohatí a mocni“", kdo dokáží přebírat odpovědnost za svůj život, když se nespoléhají na druhé, na stát, atp. Jsou to právě „bohatí a mocní", kteří přebírají odpovědnost za druhé, kterým např. dávají práci, řídí jejich práci, rozhodují o jejich dalším životě, atp. Stejně tak to jsou „bohatí a mocní", kdo utvářejí vnější

\footnotetext{
22 Srov. Gaudium et spes 11. 
podmínky současného života, čímž přebírají odpovědnost za prostředí, ve kterém žijeme, a tedy za stvoření. Mezi „bohatými a mocnými“" nakonec můžeme najít i dobré př́iklady lidí, kteří umějí převzít odpovědnost za svi̊j vztah k Bohu. Proto se domnívám, že jsou to mimo jiné právě „bohatí a mocni“", kdo dnes do značné míry ovládají umění být subjektem. Právě v našich podmínkách si můžeme často všimnout, že "chudí" se své subjektivity rádi vzdávají ve prospěch státu, druhých, církve atp., aby se stali objekty jejich péče. Jde o cestu v mnohém jednoduší, než kterou volí „bohatí a mocní".

Bohatí a mocní proto mohou zcela obecně přispět právě církvi svým příkladem, co to znamená být subjektem. Zejména $u$ „bohatých a mocných" se může církev a především pastorační profese učit, jak „dělat pastoraci“ tak, aby podporovala bytí subjektem. Právě tehdy, když pastorační práce činí lidi nepřirozeně a nezdravě závislými na pastoračních profesích a pojímá církev nikoliv jako společenství křest́anů, ale jako instituci, potlačuje jejich subjektivitu zpronevěřuje se Božímu povolání pro člověka a lidské odpovědi na toto povolání vlastně přímo brání. Právě proto se pro mnoho lidí církev a pastorační práce stávají nepřijatelnými. V souvislosti s doposud uvedeným by bylo možné uvažovat dokonce o tom, zda právě proto, že pastorační práce $\mathrm{v}$ praxi subjektivitu člověka spíše potlačuje, než podporuje, najdeme mezi křest'any tak málo „bohatých a mocných“.

„Bohatí a mocní" ale mohou dát svou subjektivitu nejen církvi. Sociální pastoraci by bylo přiměřené, aby „bohatí a mocní" dávali svou subjektivitu především „chudým". „Bohatí a mocní" mohou chudým nabídnout právě své zkušenosti s bytím subjektem - přebírání odpovědnosti za druhé, sebe a vztah ke stvoření.

\section{Závěr}

Z hlediska sociální pastorace, resp. jejího pojetí u Steinkampa, je zřejmé, že pastorace bohatých může spočívat $\mathrm{v}$ jejich zapojení do opce pro chudé, která by měla být vlastní celé církvi. Toto zapojení pak spočívá v umožnění vzájemné inspirace „chudých“ a „bohatých a mocných“, kdy se "bohatí a mocní" mohou učit od „chudých“ žít prostším způsobem života, kdy se tak chudí stávají svědky Ježíše Krista jako pravého filosofa a pravého pastýře. Zároveň se mohou také "chudí“ učit od „bohatých a mocných“, co to znamená, být v životě subjektem. To přirozeně platí především v našem kontextu, ve kterém se „chudi““ často rádi vzdávají své odpovědnosti ve prospěch někoho, od koho očekávají, že se o ně postará. Současný společenský vývoj v Evropě však vzbuzuje pochybnosti, zda je takové očekávání reálné a zda kdy skutečně reálné vůbec bylo.

\section{Bohatí a mocní jako subjekty sociální pastorace}

Abstrakł Přispěvek vychází z koncepce sociální pastorace Hermanna Steinkampa, která jednak umožňuje, vnímat bohaté a mocné jako inspiraci pro pastoraci, jednak dává i návod, jak k pastoraci bohatých a mocných přistupovat.

Klíčová slova pastorace, bohatství, moc, sociální pastorace, evangelizace, obraz Boha 